\title{
KONTRIBUSI KEPEMIMPINAN, MOTIVASI KERJA, IKLIM KERJA DAN KEPUASAN KERJA TERHADAP KOMITMEN PEGAWAI LABORATORIUM DI UNDIKSHA
}

\author{
I Gede Siden Sudaryana, Made Yudana, Sudirman \\ Program Studi Administrasi Pendidikan, Program Pascasarjana \\ Universitas Pendidikan Ganesha \\ Singaraja, Indonesia
}

e-mail: \{siden.sudaryana, made.yudana, sudirman\}@pasca.undiksha.ac.id,

\begin{abstract}
Abstrak
Penelitian ini bertujuan untuk mengetahui kontribusi kepemimpinan, motivasi kerja, iklim kerja dan kepuasan kerja terhadap komitmen pegawai laboratorium di Undiksha. Penelitian ini adalah penelitian "expost facto" dengan besar sampel 47 orang. Data dikumpulkan dengan kuesioner dan dokumen. Analisis data dilakukan dengan teknik regresi sederhana, regresi ganda, dan korelasi parsial. Hasil penelitian menunjukkan bahwa: 1) ada kontribusi yang signifikan antara kepemimpinan terhadap komitmen pegawai Laboratorium di Undiksha dengan koefisien korelasi sebesar 0,748 dan sumbangan efektifnya sebesar $24,37 \%$. 2) ada kontribusi yang signifikan antara motivasi kerja terhadap komitmen pegawai Laboratorium di Undiksha. dengan koefisien korelasi sebesar 0,604 dan sumbangan efektifnya sebesar $13,91 \%$. 3) ada kontribusi yang signifikan antara iklim kerja terhadap komitmen pegawai Laboratorium di Undiksha dengan koefisien korelasi sebesar 0,692 dan sumbangan efektifnya sebesar 20,59\%. 4) ada kontribusi yang signifikan antara kepuasan kerja terhadap komitmen pegawai Laboratorium di Undiksha dengan koefisien korelasi sebesar 0,664 dan sumbangan efektifnya sebesar 20,44\%. 5) secara bersama-sama, ada kontribusi yang signifikan antara kepemimpinan, motivasi kerja, iklim kerja, dan kepuasan kerja terhadap komitmen pegawai Laboratorium di Undiksha dengan koefisien korelasi ganda sebesar 0,891 dan kontribusinya sebesar 79,3\% terhadap komitmen pegawai Laboratorium di Undiksha.
\end{abstract}

Kata kunci: kepemimpinan, motivasi kerja, iklim kerja, kepuasan kerja, komitmen pegawai

\begin{abstract}
This study aims to determine the contribution of leadership, work motivation, work climate and job satisfaction to the commitment of laboratory employees in Undiksha. This research is an "ex-post facto" research with a large sample of 47 people. Data were collected with questionnaires and documents. Data analysis was performed by simple regression, multiple regression, and partial correlation. The results showed that: 1) there was a significant contribution between leadership to the commitment of laboratory employees in Undiksha with a correlation coefficient of 0.748 and effective contribution of $24.37 \%$. 2) there is a significant contribution between the motivation of work towards the commitment of laboratory workers in Undiksha. with a correlation coefficient of 0.604 and effective contribution of $13.91 \%$. 3) there is a significant contribution between the working climate to the commitment of laboratory workers in Undiksha with a correlation coefficient of 0.692 and effective contribution of $20.59 \%$. 4) there is a significant contribution between job satisfaction to the commitment of Laboratory employees in Undiksha with correlation coefficient of 0.664 and effective contribution of $20.44 \%$. 5) jointly, there is a significant contribution between leadership, work motivation, work climate, and job satisfaction on the commitment of laboratory employees in Undiksha with a coefficient of double correlation of 0.891 and its contribution of $79.3 \%$ to the commitment of laboratory employees in Undiksha.
\end{abstract}

Keywords: leadership, work motivation, work climate, job satisfaction, employee commitment

\section{PENDAHULUAN}

Universitas Pendidikan Ganesha memiliki sejumlah pegawai laboratorium yang menjadi bagian dari pegawai di lingkungan Undiksha Singaraja. Pegawai yang menangani laboratorium yang disebut dengan nama laboran/teknisi yang bertugas di laboratorium diharapkan dapat membantu proses belajar mengajar yang efektif dan efisien. Tenaga laboran/teknisi tersebut 
yang memiliki jabatan fungsional umum dengan kenaikan pangkat setiap 4 tahun sekali. Di lembaga Undiksha, pegawai laboratorium yang ditugaskan di laboratorium sebagian besar sudah sesesuai dengan kualitas tugas yang diembannya. Adapun tugas atau tupoksi (tugas pokok dan fungsi) dari pegawai laboratorium diatur sesuai dengan peraturan bersama.

Selain itu, Pegawai laboratorium adalah sebagai jabatan fungsional tertentu, dengan atasan langsung pegawai laboratorium adalah ketua laboratorium di masing-masing Fakultas. Jenjang karier/kenaikan pangkat pegawai laboratorium didapat dengan perolehan/pengumpulan angka kredit mereka di laboratorium. Tim penilai untuk jenjang ahli adalah langsung dinilai oleh pemeriksa pusat di Jakarta, sedang jenjang dibawahnya dinilai oleh tim penilai lembaga pendidikan Undiksha dengan jenjang yang lebih tinggi. Sehingga penilaian untuk jenjang terampil adalah tugas dari tim penilai angka kredit tingkat pegawai laboratorium ahli, dan diketahui oleh kepala laboratorium.

Salah satu unsur yang paling penting mempengaruhi kualitas seorang pegawai adalah komitmen kerja pegawai. Komitmen didefinisikan oleh beberapa peneliti sebagai ukuran dari kekuatan identitas dan keterlibatan karyawan dalam tujuan dan nilai-nilai yang pada sebuah lembaga. Komitmen berkaitan dengan pencapaian pada pemberdayaan lembaga karena dengan komitmen yang diberikan, diharapkan kinerja dari pegawainya akan meningkat dengan sikap yang merefleksikan loyalitas kepada lembaga.

Komitmen pada setiap pegawai sangat penting karena dengan suatu komitmen seorang pegawai dapat menjadi lebih bertanggung jawab terhadap pekerjaannya dibanding dengan pegawai yang tidak mempunyai komitmen. Biasanya pegawai yang memiliki suatu komitmen, akan bekerja secara optimal sehingga dapat mencurahkan perhatian, pikiran, tenaga dan waktunya untuk pekerjaanya. Sehingga apa yang sudah dikerjakannya sesuai dengan yang diharapkan oleh lembaga. Maka dengan berkomitmen pun akan mengurangi intensi untuk meninggalkan sebuah lembaga.

Ada beberapa aspek yang mempengaruhi komitmen kerja pegawai, diantaranya kepemimpinan. Pegawai yang bekerja di suatu lembaga, selalu tergantung pada seorang pemimpin. Apabila pemimpin tidak memiliki kemampuan memimpin, maka tugas yang sangat kompleks tidak dapat dikerjakan dengan baik sehingga diperlukan pemimpin yang efektif dan mempunyai kemampuan untuk mempengaruhi perilaku anak buahnya. Jadi, seorang pemimpin suatu organisasi atau lembaga akan diakui sebagai seorang pemimpin apabila ia dapat memberi pengaruh dan mampu mengarahkan bawahannya ke arah tujuan organisasi/ lembaga. Peran kepemimpinan yang sangat strategis sangat penting bagi pencapaian misi, visi dan tujuan suatu organisasi selain itu merupakan salah satu motif yang mendorong manusia untuk selalu menyelidiki selukbeluk yang terkait dengan komitmen kinerjanya.

Lembaga-lembaga pendidikan perguruan tinggi dewasa ini haruslah menjadikan pegawai sebagai aset, bukan lagi hanya sebagai alat semata. Untuk itu lembaga perlu menciptakan suatu kondisi yang kondusif yang dapat membuat pegawai merasa nyaman, terpenuhi kebutuhannya, sehingga diharapkan motivasi mereka juga tetap terjaga untuk bersama sama mencapai visi dan misi lembaga. Kondisi-kondisi kondusif atau iklim kerja yang diciptakan itu bisa bermacammacam, tergantung pada karakteristik lembaga itu masing masing. Tapi secara umum diantaranya dapat berupa fasilitas yang disediakan, tingkat kesejahteraan yang memadai, jenjang karir yang jelas, peluang aktualisasi diri, kenyaman dan keamanan dalam bekerja, jaminan hari tua dan lain-lain.

Selain dari motivasi kerja dan iklim kerja, ada lagi yang dapat mempengaruhi komitmen kerja para pegawai yaitu kepuasan kerja. Kepuasan kerja para pegawai sangat penting dan besar perannya dalam kemajuan lembaga, karena bisa mempengaruhi berbagai kegiatan lembaga. Lembaga melalui manajemennya terus mengembangkan cara untuk meningkatkan kepuasan kerja pegawainya terutama pegawai-pegawai yang berprestasi dan bernilai tinggi dalam lembaga.

Kepuasan kerja pegawai menurut Hariandja (2002:291) dapat dilihat bahwa "pekerjaan tidak hanya sekedar melakukan pekerjaan, tetapi terkait juga dengan aspek lain seperti 
melakukan interaksi dengan teman sekerja, atasan, mengikuti aturan-aturan dan lingkungan kerja tertentu yang seringkali tidak memadai atau kurang disukai. Kepuasan kerja pada dasarnya merupakan hal yang bersifat individual, setiap individual memiliki tingkat kepuasan kerja yang berbeda-beda sesuai dengan keinginan dan sistem nilai yang dianutnya.

Semakin banyak aspek dalam pekerjaannya yang sesuai dengan keinginan dan sistem nilai yang dianut individu, semakin tinggi tingkat kepuasan yang didapat. Demikian pula sebaliknya, semakin banyak aspek dalam pekerjaannya yang tidak sesuai dengan keinginan dan sistem nilai yang dianut individu, semakin rendah tingkat kepuasan yang didapat. Kepuasan kerja adalah keadaan emosional yang menyenangkan dengan bagaimana para pekerja memandang pekerjaan mereka. Kepuasan kerja mencerminkan perasaan seseorang terhadap pekerjaannya yang dapat terlihat dari sikap pegawai terhadap pekerjaan dan segala sesuatu di lingkungan pekerjaannya. Semua jenis lembaga dan organisasi sebenarnya membutuhkan suatu sistem kerja yang secara serius memperhatikan hal kepuasan kerja para pegawainya.

Berdasarkan pernyataan di atas, apabila persepsi terhadap seseorang menunjukkan sebagai pemimpin yang layak dicintai, dipercaya, diikuti, mampu membimbing serta memenuhi kriteria pemimpin yang mampu memberikan representasi hati, maka hal tersebut akan mempengaruhi besarnya motivasi kerja, iklim kerja, kepusan kerja dan komitmen kerja pegawainya. Oleh karena itu, pemimpin harus mempunyai kemampuan karena tanpa kemampuan, orang tidak akan mau mengikuti dan mendengarkannya selain itu pemimpin harus dapat menggugah respect dan simpati orang lain.

Hal ini sejalan dengan penelitian yang dilakukan oleh Pancaria (2015) dengan judul "Kontribusi Efektivitas Kepemimpinan, Budaya Organisasi dan Etos Kerja Terhadap Kepuasan Kerja Pegawai Kantor Kementerian Agama Kabupaten Buleleng". Hasil penelitiannya menunjukkan bahwa: 1) terdapat kontribusi yang signifikan dari efektivitas kepemimpinan terhadap kepuasan kerja pegawai kantor Kementerian Agama Kabupaten Buleleng, 2) terdapat konstribusi yang signifikan dari budaya organisasi terhadap kepuasan kerja pegawai kantor Kementerian Agama Kabupaten Buleleng, 3) terdapat kontribusi yang signifikan dari etos kerja terhadap kepuasan kerja pegawai kantor Kementerian Agama Kabupaten Buleleng, dan 4) terdapat kontribusi yang signifikan secara bersama-sama antara efektivitas kepemimpinan, budaya organisasi dan etos kerja terhadap kepuasan kerja pegawai kantor Kementerian Agama Kabupaten Buleleng. Dengan demikian, efektivitas kepemimpinan, budaya organisasi dan etos kerja dapat dijadikan sebagai prediktor dalam peningkatan kepuasan kerja pegawai kantor Kementerian Agama Kabupaten Buleleng.

Saat ini banyak pegawai laboratorium yang kurang memiliki motivasi yang tinggi saat bekerja, sehingga berdampak pada iklim kerja yang kurang kondusip. Hal ini dibuktikan dengan menurunnya kualitas kerja pegawai laboratorium di Undiksha. Mungkin hal tersebut disebabkan oleh para pegawai laboratorium yang tidak memiliki komitmen kerja yang tinggi dan kurangnya perhatian dari atasan atau pimpinan atas kinerja para pegawai laboratorium. Kurangnya reward yang diberikan oleh lembaga kepada para pegawai laboratorium juga berdampak pada kinerja para pegawai laboratorium.

Tidak jarang pegawai laboratorium dan teknisi ditempatkan pada tempat yang tidak sesuai dengan kompetensi yang mereka miliki sehingga mereka tidak berkompeten ditempat mereka bekerja, sehingga tidak jarang menurunkan motivasi kerja mereka akibat tempat mereka bekerja tidak sesuai lagi dengan kompetensi yang mereka miliki. Keadaan seperti ini akan menyebabkan berkurangnya tanggung jawab mereka terbadap pekerjaan yang mereka kerjakan, dimana nantinya akan menguragi komitmen mereka sebagai pegawai laboratorium.

Dari latar belakang di atas, maka peneliti ingin membahas lebih jauh tentang kepemimpinan, motivasi kerja, iklim kerja dan kepuasan kerja yang dapat mempengaruhi komitmen kerja pegawai laboratorium di lingkungan lembaga Undiksha yang pada akhirnya dapat berdampak pada kinerja para pegawai tersebut. Karena di laboratorium Undiksha, ratarata pegawai selalu mempunyai masa kerja di atas 5 tahun dan jarang adanya keluar masuk pegawai. Tentunya hal ini menjadi hal yang strategis untuk diteliti, sehingga pegawai memiliki 
komitmen yang cukup tinggi. Penelitian ini bertujuan untuk menguji apakah terdapat kontribusi kepemimpinan, motivasi kerja, iklim kerja dan kepuasan kerja terhadap komitmen pegawai di laboratorium Undiksha.

\section{METODE PENELITIAN}

Penelitian ini termasuk penelitian non-treatment atau ex-post facto karena tidak dilakukan perlakuan pada variabel dan hanya mengambil data secara langsung. Lebih lanjut, penelitian ini termasuk pendekatan kuantitatif dengan rancangan korelasional karena dalam penelitian ini mencoba mengetahui hubungan yang ada, antar variabel yang dikorelasikan (Koyan, 2012:105). Hasil penelitian hanyalah mendeskripsikan dan menganalisis hubungan antara kepemimpinan, motivasi kerja, iklim kerja, dan kepuasan kerja terhadap komitmen pegawai laboratorium di Undiksha.

Menurut Sugiyono (2009:61) populasi adalah wilayah generalisasi yang terdiri atas objek dan subjek yang mempunyai kualitas dan karakteristik tertentu yang ditetapkan oleh peneliti untuk dipelajari dan kemudian ditarik kesimpulannya. Pendapat lain mengenai populasi dikemukakan oleh Ridwan dalam Bhucari (2009:55) yang menyatakan bahwa populasi adalah keseluruhan dari karakteristik atau unit hasil pengukuran yang menjadi objek penelitian.

Dari pendapat para ahli tersebut dapat ditarik kesimpulan bahwa populasi adalah subjek atau objek yang menjadi pusat penelitian yang memenuhi syarat-syarat tertentu yang berkaitan dengan masalah penelitian dalam suatu wilayah. Populasi dalam penelitian ini adalah seluruh pegawai laboratorium di Undiksha yang berjumlah 47 pegawai. Dalam penelitian ini teknik penentuan sampel yang digunakan adalah sampling jenuh atau sensus. Pengertian dari sampling jenuh atau sensus menurut Sugiyono (2008:122) adalah: Sampling jenuh atau sensus adalah teknik penentuan sampel bila semua anggota populasi digunakan sebagai sampel. Berdasarkan dari pengertian tersebut, maka dapat diketahui bahwa sampling jenuh atau sensus teknik penentuan sampel dengan menggunakan semua anggota populasi yaitu berjumlah 47 pegawai laboratorium.

Variabel yang diteliti dalam penelitian ini meliputi variabel bebas (independent variable) dan variabel terikat (dependent variable). Variabel bebas $(X)$ yaitu variabel yang mempengaruhi variabel terikat. Sedangkan variabel terikat $(Y)$ adalah variabel yang dipengaruhi akibat adanya variabel bebas. Dalam penelitian ini variabel bebas meliputi: kepemimpinan $\left(X_{1}\right)$, motivasi kerja $\left(X_{2}\right)$, iklim kerja $\left(X_{3}\right)$ dan kepuasan kerja $\left(X_{4}\right)$. Sebagai variabel terikat adalah komitmen pegawai laboratorium Undiksha $(\mathrm{Y})$.

Untuk pengumpulan data tentang kepemimpinan, motivasi kerja, iklim kerja, kepuasan kerja dan komitmen pegawai digunakan kuesioner dengan pola skala likert. Sementara itu, Riduwan (2005:25) berpendapat bahwa "angket (questionnaire) adalah daftar pertanyaan yang diberikan kepada orang lain yang bersedia memberi respons (responden) sesuai dengan permintaan pengguan. Sedangkan untuk memperoleh jumlah pegawai yang ada di masing-masing bagian digunakan metode dokumen, serta metode observasi digunakan sebagai metode pelengkap".

Alat pengumpul data harus memenuhi persyaratan yaitu syarat validitas dan reliabilitas dalam mengungkap apa yang hendak diukur. Ada dua persyaratan yang hendak digunakan dalam pengumpulan data penelitian yaitu validitas dan reliabilitas (Hamzah, $2001: 63$ ). Validitas instrumen dalam penelitian ini meliputi dua segi yaitu validitas isi dan validitas butir. Validitas isi dibantu oleh dua orang ahli/ expert, kemudian dianalisis dengan teknik Gregory.

Sebelum instrumen digunakan, maka perlu diuji dahulu validitas dari masing-masing pertanyaan yang ada sebagai alat pengambilan data. Dengan demikian terlebih dahulu diadakan uji coba terhadap kuisioner kemudian hasil uji coba ini dianalisis. Untuk menguji validitas butir rumus yang digunakan adalah rumus kontribusi product moment dari Pearson (Arikunto, 1995).

Pengujian terhadap reabilitas instrumen dilakukan melalui pendekatan ketetapan internal. Uji reliabilitas adalah ketepatan dan keajegan alat pengukur tersebut dalam menilai apa yang diinginkan, artinya kapanpun alat tersebut digunakan akan diperoleh hasil yang sama (Puger, 2004). Pengujian reliabilitas dengan rumus Alpha dari Crombach (Arikunto, 1997:164). 
Kegiatan analisis data terdiri atas kegiatan pengolahan data dan analisis statistik. Kegiatan analisis data meliputi: 1) menyunting data secara manual. Penyuntingan dilakukan karena kemungkinan ada data yang tidak jelas, atau kesalahan dalam pengisian instrument, sehingga tidak memenuhi syarat untuk dianalisis, 2) mentabulasi data, dan 3) mengolah data dalam bentuk sesuai kebutuhan.

Untuk menguji hipotesis yang telah dirumuskan, terlebih dahulu dilakukan analisis data yang telah dikumpulkan. Dalam melakukan analisis data untuk penelitian ini dilakukan dengan tiga tahapan yakni: 1) tahap deskripsi data, 2) tahap pengujian persyarat analisis, 3) tahap pengujian hipotesis.

Data yang telah diperoleh dari penelitian dideskripsikan menurut masing-masing variable. Oleh tujuannya seperti itu, maka akan dicari harga rerata (M), standar deviasi (SD), modus (Mo), dan median $(\mathrm{Me})$ setiap variabel yang diteliti.

Setelah data dideskripsikan, maka analisis dilanjutkan dengan menggunakan teknik regresi sederhana, regresi ganda, dan korelasi varsial. Persyaratan yang berkaitan dengan teknik analisis data tersebut harus dibuktikan secara statistik.

Setelah seluruh uji prasyarat terpenuhi, maka dilanjutkan dengan uji hipotesis. Untuk menguji hipotesis pertama, kedua, ketiga dan keempat dalam penelitian ini digunakan teknik analisis korelasi sederhana (korelasi product moment pearson). Sedangkan untuk menguji hipotesis ke lima, digunakan teknik analisis korelasi ganda, regresi ganda, dan korelasi parsial. Untuk menganalisis uji hipotesis dalam penelitian ini digunakan program SPSS-17.00 for windows.

\section{HASIL PENELITIAN DAN PEMBAHASAN}

\section{Kontribusi Kepemimpianan terhadap Komitmen Pegawai Laboratorium di Undiksha}

Berdasarkan analisis data yang telah dilakukan, Secara normatif ditemukan bahwa kepemimpinan berada pada kategori sangat baik. Selain itu, hasil analisis juga menunjukkan bahwa terdapat korelasi yang signifikan antara kepemimpinan dengan komitmen pegawai Laboratorium di Undiksha melalui persamaan garis regresi $\hat{y}=10,730+0,965 . X_{1}$ dengan Freg $=$ $57,258(p<0,05)$. Sedangkan korelasi yang signifikan terjadi antara kepemimpinan dengan komitmen pegawai sebesar 0,748 dengan $\mathrm{p}<0,05$ dan variabel kepemimpinan dapat menjelaskan komitmen pegawai Laboratorium di Undiksha sebesar 56\%. Temuan ini mengindikasikan bahwa kepemimpinan mempunyai peranan penting dalam meningkatkan komitmen pegawai Laboratorium di Undiksha. Sumbangan efektif (SE) variabel kepemimpinan terhadap komitmen pegawai Laboratorium di Undiksha adalah sebesar 24,37\%.

Temuan dalam penelitian ini sejalan dengan temuan penelitian yang dilakukan oleh Rabindarang dan Khuan (2012) dengan judul Hubungan Kepemimpinan Distributif Terhadap Komitmen Organisasi dan Tekanan Kerja dalam Pendidikan Teknik dan Vokasional. Hasil kajian menunjukkan kepemimpinan distributif mempunyai hubungan signifikan dengan komitmen organisasi dan hubungan tidak signifikan dengan tekanan kerja. Kertasini akan membentangkan latar belakang masalah kajian, sorotan kajian literatur, kepemimpinan distributif, komitmen organisasi dan tekanan kerja. Kajian ini dapat menyumbangkan kepada penerapan kepemimpinan distributif dalam peningkatan komitmen organisasi. Dengan ini, organisasi dapat mencapai kejayaan dan seiring dengan perubahan semasa dalam bidang pendidikan teknik dan vokasional.

Hubungan kepemimpinan dapat dikaji bahwa atasan merupakan sumber motivator, agen perubahan yang tentunya perilakunya di dalam melaksanakan tugasnya sebagai pemimpin akan sangat mempengaruhi perilaku bawahannya, maka sekaligus akan mempengaruhi komitmennya.

Pegawai yang merasa segan dengan pimpinan tentu akan merasa malu jika menunjukan komitmen yang di bawah standar. Oleh karena itu, pimpinan yang memiliki perilaku yang baik akan menginspirasi pegawai untuk bekerja. Sehingga bisa diprediksi bahwa kepemimpinan akan berkontribusi terhadap komitmen pegawai Laboratorium di Undiksha. Berdasarkan pemaparan 
di atas, maka dapat disimpulkan bahwa kepemimpinan memberikan kontribusi yang signifikan terhadap komitmen pegawai Laboratorium di Undiksha.

\section{Kontribusi Motivasi kerja Terhadap Komitmen Pegawai Laboratorium di Undiksha}

Berdasarkan analisis data yang telah dilakukan, secara normatif ditemukan bahwa motivasi kerja berada pada kategori sangat baik. Selain itu, hasil analisis juga menunjukkan bahwa terdapat korelasi yang signifikan antara motivasi kerja dengan komitmen pegawai Laboratorium di Undiksha melalui persamaan garis regresi $\hat{y}=30,250+0,703 X_{2}$ dengan Freg $=25,858$ $(p<0,05)$. Sedangkan korelasi yang signifikan terjadi antara motivasi kerja dengan komitmen pegawai sebesar 0,604 dengan $p<0,05$ dan variabel motivasi kerja dapat menjelaskan Laboratorium di Undiksha sebesar $36,5 \%$. Temuan ini mengindikasikan bahwa motivasi kerja mempunyai peranan penting dalam meningkatkan komitmen pegawai Laboratorium di Undiksha. Sumbangan efektif (SE) variabel motivasi kerja terhadap komitmen pegawai Laboratorium di Undiksha adalah sebesar $13,91 \%$.

Temuan dalam penelitian ini sejalan dengan temuan penelitian yang dilakukan oleh Thaiban, dkk (2014) dengan Judul Pengaruh Kepemimpinan Kepala Sekolah dan Motivasi Kerja Terhadap Komitmen Kerja Guru Di SMP Negeri Kecamatan Sungai Limau Kabupaten Padang Pariaman. Hasil penelitian ini menemukan bahwa: Kepemimpinan kepala sekolah berpengaruh signifikan terhadap motivasi kerja dan komitmen kerja guru SMP Negeri di Kecamatan Sungai Limau Kabupaten Padang Pariaman. Serta motivasi kerja berpengaruh signifikan terhadap komitmen kerja guru SMP Negeri di Kecamatan Sungai Limau Kabupaten Padang Pariaman.

Motivasi kerja merupakan kemauan atau kekuatan yang mendorong seseorang untuk melakukan kegiatan atau tugas yang harus dilaksanakan. Kemauan itu dikaitkan dalam upaya seseorang bagaimana meningkatkan kerja. Seseorang yang termotivasi adalah orang yang berupaya meningkatkan kerjanya dalam upaya mencapai tujuan. Motivasi juga dikaitkan dengan kebutuhan, kemampuan dan persepsi seseorang tentang pekerjaan. Semakin kuat motivasi yang ada pada diri pegawai dalam melaksanakan tugasnya maka prestasi kerja mereka akan semakin baik. Motivasi kerja pegawai akan mempengaruhi perilaku dalam melakukan tugas pekerjaanya.

Pegawaiyang mempunyai motivasi kerja yang tinggi dan tidak hanya untuk kepentingan dirinya, akan dapat melakukan tugas dengan tepat, sesuai dengan profesinya sebagai pegawai. Sehingga diprediksi motivasi kerja berkontribusi secara signifikan terhadap komitmen kerja pegawai di lingkungan Undiksha.

\section{Kontribusi Iklim Kerja Terhadap Komitmen Pegawai Laboratorium di Undiksha}

Berdasarkan analisis data yang telah dilakukan, secara normatif ditemukan bahwa iklim kerja berada pada kategori sangat baik. Selain itu, hasil analisis juga menunjukkan bahwa terdapat korelasi yang signifikan antara iklim kerja dengan komitmen pegawai Laboratorium di Undiksha melalui persamaan garis regresi $\hat{y}=0,468+0,940 X_{3}$ dengan Freg $=41,447(p<0,05)$. Sedangkan korelasi yang signifikan terjadi antara iklim kerja dengan komitmen pegawai sebesar 0,692 dengan $\mathrm{p}<0,05$ dan variabel iklim kerja dapat menjelaskan komitmen pegawai Laboratorium di Undiksha sebesar $47,9 \%$. Temuan ini mengindikasikan bahwa iklim kerja mempunyai peranan penting dalam meningkatkan komitmen pegawai Laboratorium di Undiksha. Sumbangan efektif (SE) variabel iklim kerja terhadap komitmen pegawai Laboratorium di Undiksha adalah sebesar $20,59 \%$.

Hasil penelitian ini sejalan dengan hasil penelitian yang dilakukan oleh Mangkunegara (2015) dengan judul Effect of Work Discipline, Work Motivation and Job Satisfaction on Employee Organizational Commitment in the Company (Case Study in PT. Dada Indonesia). This study analyzed the influence of Work Discipline, Work Motivation and Job Satisfaction on Organizational Commitment employees in staffing levels. Object of this study is the level of staff employees at PT. Dada Indonesia. The research problem refers to the phenomenon of the data on the PT. Dada Indonesia, which indicated the level of absenteeism or employee absenteeism average - average to reach 4-5 percent. The problem that arises is: how to improve employee 
Organizational Commitment. A modeling has been constructed and 4 (four) research hypotheses have been formulated. This researched used Proportional Random Sampling. The study used 148 respondents and the overall level of staff respondents were employees of PT. Dada Indonesia. The results of this study show them that Work Discipline has positive effect on Organizational Commitment. Work Motivation has positive effect on Organizational Commitment. Job satisfaction has positive influence on Organizational Commitment. Work discipline, work motivation and job satisfaction has positive influence on Organizational Commitment.

Iklim kerja adalah suasana di tempat kelompok itu berada yang memberi kesan kepada semua anggota, bahwa mereka dianggap setara. Dari pengertian ini dapat diartikan bahwa suasana kerja yang baik jika dalam suatu organisasi kerja dapat memberi kesan kepada semua anggota organisasi bahwa tidak ada perbedaan perlakuan atau pemberian perlakuan yang istimewa pada salah satu anggota organisasi. Dengan demikian, dengan iklim kerja yang baik dan harmonis maka akan menciptakan iklim dan keadaan kerja yang kondusip sehingga dapat berdampak pada komitmen kerja pegawai yang baik.

Pegawai yang mempunyai iklim kerja yang tinggi dan tidak hanya untuk kepentingan dirinya, akan dapat melakukan tugas dengan tepat, sesuai dengan profesinya sebagai pegawai. Sehingga iklim kerja berkontribusi secara signifikan terhadap komitmen pegawai Laboratorium di Undiksha. Berdasarkan pemaparan di atas, maka dapat disimpulkan bahwa iklim kerja memberikan kontribusi yang signifikan terhadap komitmen pegawai Laboratorium di Undiksha.

\section{Kontribusi Kepuasan Kerja Terhadap Komitmen Pegawai Laboratorium di Undiksha}

Berdasarkan analisis data yang telah dilakukan, secara normatif ditemukan bahwa kepuasan kerja berada pada kategori sangat baik. Selain itu, hasil analisis juga menunjukkan bahwa terdapat korelasi yang signifikan antara kepuasan kerja dengan komitmen pegawai Laboratorium di Undiksha melalui persamaan garis regresi $\hat{y}=1,486+0,903 \mathrm{X}_{4}$ dengan Freg $=$ $35,423(p<0,05)$. Sedangkan korelasi yang signifikan terjadi antara kepuasan kerja dengan komitmen pegawai sebesar 0,664 dengan $\mathrm{p}<0,05$ dan variabel kepuasan kerja dapat menjelaskan komitmen pegawai Laboratorium di Undiksha sebesar 44\%. Temuan ini mengindikasikan bahwa kepuasan kerja mempunyai peranan penting dalam meningkatkan komitmen pegawai Laboratorium di Undiksha. Sumbangan efektif (SE) variabel kepuasan kerja terhadap komitmen pegawai Laboratorium di Undiksha adalah sebesar 20,44\%.

Hasil penelitian ini sejalan dengan hasil penelitian yang dilakukan oleh Puspita, dkk, (2017) dengan judul "Pengaruh Keterlibatan Kerja (Job Involvement) dan Kepuasan Kerja (Job Satisfaction) Terhadap Komitmen Organisasi Pegawai Pusdikbang SDM Perum Perhutani Madiun". Hasil penelitian menunjukkan bahwa: (1) Keterlibatan Kerja (Job Involvement) berpengaruh signifikan terhadap Komitmen Organisasi Pegawai Pusdikbang SDM Perum Perhutani Madiun (2) Kepuasan Kerja (Job Satisfaction) berpengaruh signifikan terhadap Komitmen Organisasi Pegawai Pusdikbang SDM Perum Perhutani Madiun (3) Keterlibatan Kerja (Job Involvement) dan Kepuasan Kerja (Job Satisfaction) secara simultan memiliki pengaruh signifikan terhadap Komitmen Organisasi Pegawai Pusdikbang SDM Perum Perhutani Madiun.

Salah satu sarana penting pada manjemen sumber daya manusia dalam sebuah orgaisasi adalah terciptanya kepuasan kerja para pegawai/ karyawan. Berikut pengertian-pengertian kepuasan kerja menutur beberapa pakar. Kepuasan kerja menurut Martoyo (1992:115), pada dasarnya merupakan salah satu aspek psikologis yang mencerminkan perasaan seseorang terhadap pekerjaannya,ia akan merasa puas dengan adanya kesesuaian antara kemampuan, keterampilan dan harapannya dengan pekerjaan yang ia hadapi.

Kepuasan sebenarnya merupakan keadaan yang sifatnya subyektif yang merupakan hasil kesimpulan yang didasarkan pada suatu perbandingan mengenai apa yang diterima pegawai dari pekerjaannya dibandingkan dengan yang diharapkan, diinginkan, dan dipikirkannya sebagai hal yang pantas atau berhak atasnya. Sementara setiap karyawan/pegawai secara subyektif menentukan bagaimana pekerjaan itu memuaskan. 
Pegawai yang mempunyai kepuasan kerja yang tinggi akan dapat melakukan tugas dengan baik dan penuh semangat. Sehingga diprediksi kepuasan kerja berkontribusi secara signifikan terhadap komitmen kerja pegawai di lingkungan Undiksha.

\section{Kontribusi Bersama-Sama Kepemimpinan, Motivasi kerja dan Iklim Kerja Terhadap Komitmen Pegawai Laboratorium di Undiksha}

Berdasarkan analisis yang telah dilakukan, ditemukan bahwa terdapat korelasi yang signifikan secara bersama-sama antara kepemimpinan kepala sekolah, motivasi kerja, iklim kerja, dan kepuasan kerja terhadap komitmen pegawai melalui persamaan garis regresi $\hat{y}=$ $88,911+0,420 X_{1}+0,268 X_{2}+0,404 X_{3}+0,419 X_{4}$ dengan Freg $=40,275(p<0,05)$. Ini berarti terdapat hubungan secara bersama-sama antara kepemimpinan, motivasi kerja, iklim kerja, dan kepuasan kerja terhadap komitmen pegawai Laboratorium di Undiksha. Hal ini mengindikasikan bahwa makin baik kepemimpinan, motivasi kerja, iklim kerja, dan kepuasan kerja makin baik pula komitmen pegawai tersebut.

Korelasi murni antara kepemimpinan, motivasi kerja, iklim kerja, dan kepuasan kerja dengan komitmen pegawai Laboratorium di Undiksha yang diperoleh melalui analisis korelasi parsial jenjang kedua. Hasil yang diperoleh adalah: pertama, terdapat korelasi yang signifikan antara variabel kepemimpinan terhadap komitmen pegawai dengan dikendalikan oleh variabel motivasi kerja, iklim kerja, dan kepuasan kerja $\left(r_{1 y-234}=0,748\right)$ dengan $\left.p<0,05\right)$. Ini menunjukkan bahwa kepemimpinan memberikan kontribusi yang signifikan terhadap komitmen pegawai Laboratorium di Undiksha, sehingga dapat dijadikan prediktor kecenderungan tingkat komitmen pegawai Laboratorium di Undiksha.

Kedua, terdapat korelasi yang signifikan motivasi kerja terhadap komitmen pegawai dengan dikendalikan oleh variabel kepemimpinan, iklim kerja, dan kepuasan kerja $\left(r_{2 y-134}=0,604\right.$ dengan $p>0,05)$. Ini menunjukkan bahwa motivasi kerja memberikan kontribusi terhadap komitmen pegawai Laboratorium di Undiksha, sehingga dapat dijadikan prediktor kecenderungan tingkat komitmen pegawai Laboratorium di Undiksha.

Ketiga, terdapat korelasi yang signifikan antara iklim kerja terhadap komitmen pegawai dengan dikendalikan oleh variabel kepemimpinan, motivasi kerja, dan kepuasan kerja $\left(r_{3 y-124}=\right.$ $0,692$ dengan $p>0,05)$. Ini menunjukkan bahwa iklim kerja memberikan kontribusi terhadap komitmen pegawai Laboratorium di Undiksha, sehingga dapat dijadikan prediktor kecenderungan tingkat komitmen pegawai Laboratorium di Undiksha.

Keempat, terdapat korelasi yang signifikan antara kepuasan kerja terhadap komitmen pegawai dengan dikendalikan oleh variabel kepemimpinan, motivasi kerja dan iklim kerja ( $\mathrm{r}_{4 y-123}$ $=0,664$ dengan $p>0,05)$. Ini menunjukkan bahwa kepuasan kerja memberikan kontribusi terhadap komitmen pegawai Laboratorium di Undiksha, sehingga dapat dijadikan prediktor kecenderungan tingkat komitmen pegawai Laboratorium di Undiksha.

Kekuatan hubungan keempat variabel bebas dengan komitmen pegawai Laboratorium di Undiksha secara berurutan adalah: kepemimpinan, motivasi kerja, iklim kerja, dan kepuasan kerja mempunyai kontribusi terhadap komitmen pegawai.

\section{PENUTUP}

Berdasarkan hasil penelitian dan pembahasan yang telah dilakukan, maka dapat ditarik kesimpulan sebagai berikut.

Pertama, ada kontribusi yang signifikan antara kepemimpinan terhadap komitmen pegawai Laboratorium di Undiksha dengan koefisien korelasi sebesar 0,748 dan sumbangan efektifnya sebesar $24,37 \%$.

Kedua, ada kontribusi yang signifikan antara motivasi kerja terhadap komitmen pegawai Laboratorium di Undiksha. dengan koefisien korelasi sebesar 0,604 dan sumbangan efektifnya sebesar $13,91 \%$. 
Ketiga, ada kontribusi yang signifikan antara iklim kerja terhadap komitmen pegawai Laboratorium di Undiksha dengan koefisien korelasi sebesar 0,692 dan sumbangan efektifnya sebesar $20,59 \%$.

Keempat, ada kontribusi yang signifikan antara kepuasan kerja terhadap komitmen pegawai Laboratorium di Undiksha dengan koefisien korelasi sebesar 0,664 dan sumbangan efektifnya sebesar $20,44 \%$.

Kelima, secara bersama-sama, ada kontribusi yang signifikan antara kepemimpinan, motivasi kerja, iklim kerja, dan kepuasan kerja terhadap komitmen pegawai Laboratorium di Undiksha dengan koefisien korelasi ganda sebesar 0,891 dan kontribusinya sebesar 79,3\% terhadap komitmen pegawai Laboratorium di Undiksha.

Berdasarkan hasil dan kesimpulan dari penelitian ini, dapat diajukan beberapa saran sebagai berikut.

1. Bagi Pimpinan

Dalam hal ini adalah Ketua Lab hendaknya dapat meningkatkan komitmen pegawai Laboratorium dengan merefleksikan loyalias dan peduliannya, dengan demikian pegawai laboratorium mendapat perhatian dari Ketua Lab, sehingga termotivasi untuk melaksanakan Tupoksinya, yang secara tidak langsung berpengaruh pada kemajuan Undiksha.

2. Bagi Pegawai Laboratorium

Diharapkan dapat meningkatkan komitmen kerja sesuai tupoksi, dengan demikian Pegawai Laboratorium dapat mengembangkan jenjang dan karir mereka di Labortorium dalam iklim kerja yang aman dan nyaman.

3. Bagi Peneliti Lain

Diharapkan mampu mengembangkan variabel lain dalam usaha meningkatkan komitmen pegawai laboratorium, sehingga memberikan kontribusi pengetahuan yang lebih luas khususnya dibidang Laboratorium.

\section{DAFTAR RUJUKAN}

Arikunto, Suharsimi. 1995. Manajemen Penelitian. Jakarta: Rineka Cipta.

Arikunto, Suharsimi. 1997. Prosedur Penelitian Suatu Pendekatan Praktek. Jakarta: Rineka Cipta.

Buchari, Alma. 2009. Manajemen Pemasaran dan Pemasaran Jasa, Cetakan kedelapan. Bandung: Alfabeta.

Hamzah, B. Uno. 2007. Teori Motivasi dan Pengukurannya. Jakarta: Bumi Aksana.

Hariandja, Marihot T.E, 2002. Manajemen Sumber Daya Manusia. Jakarta: Grasindo.

Koyan, I Wayan. 2012. Statistik Pendidikan. Singaraja: Universitas Pendidikan Ganesha Press.

Mangkunegara, A.P. 2015. Effect of Work Discipline, Work Motivation and Job Satisfaction on Employee Organizational Commitment in the Company (Case Study in PT. Dada Indonesia). Universal Journal of Management 3(8): 318-328, 2015.

Martoyo, Susilo. 1992. Manajemen Sumber Daya Manusia. Yogyakarta: BPFE.

Pancaria, I Nyoman. 2015. Kontribusi Efektivitas Kepemimpinan, Budaya Organisasi dan Etos Kerja Terhadap Kepuasan Kerja Pegawai Kantor Kementerian Agama Kabupaten Buleleng. e-Journal Program Pascasarjana Universitas Pendidikan Ganesha.Program Studi Administrasi Pendidikan Volume 6, No 1.

Puger, I Gusti Ngurah. 2004. Belajar Kooperatif. Diktat Perkuliahan Mahasiswa Unipas. 
Puspita, dkk. 2017. Pengaruh Keterlibatan Kerja (Job Involvement) dan Kepuasan Kerja (Job Satisfaction) Terhadap Komitmen Organisasi Pegawai Pusdikbang SDM Perum Perhutani Madiun. The 9th FIPA: Forum IImiah Pendidikan Akuntansi - Universitas PGRI MadiunVol. 5 No. 1 HImn. 364-380.

Rabindarang, Siva dan Khuan Wai Bing. 2012. Hubungan Kepemimpinan Distributif Terhadap Komitmen: Organisasi dan Tekanan Kerja dalam Pendidikan Teknik dan Vokasional. National Research \& Innovation Conference for Graduate Students in Social Sciences (GSNRIC 2012).

Riduwan. 2005. Skala Pengukuran Variabel-variabel Penelitian. Bandung: Alfabeta.

Sugiyono. 2008. Metode Penelitian pedidikan pendekatan kuantitatif, kualitatif, dan R\&D. Bandung: Alfabeta.

Sugiyono. 2009. Statistika Untuk Penelitian. Bandung: Alfabeta.

Thaiban, dkk. 2014. Pengaruh Kepemimpinan Kepala Sekolah dan Motivasi Kerja Terhadap Komitmen Kerja Guru Di SMP Negeri Kecamatan Sungai Limau Kabupaten Padang Pariaman. e Journal. 